Jurnal Ilmu Keperawatan : Journal of Nursing Science 2020, Vol. 8, No. 1, 60-67

www.jik.ub.ac.id

Doi 10.21776/ub.jik.2020.008.01.1

P-ISSN: 2088-6012 E-ISSN: 2598-8492

Research article

\title{
THE EFFECT OF FOOT SOAK THERAPY USING WARM WATER TOWARD ANXIETY LEVEL OF PREECLAMPSIA MOTHERS IN PUBLIC HEALTH OF TEMPUREJO JEMBER REGENCY
}

Rhozy Sadya Mangrasih $^{1 *}$, Dini Kurniawati ${ }^{1}$, Peni Perdani Juliningrum ${ }^{1}$

Afiliasi

1. Faculty of Nursing, Jember University

Dikirim 30 Juli 2019

Direvisi 19 Mei 2020

Diterima 1 Juni 2020

Dipublikasi 30 Juni 2020

*Korespondensi

Email :

rhozysadya@gmail.com

\begin{abstract}
ABSTRAK
Salah satu gangguan psikologi pada ibu preeclampsia adalah kecemasan . Salah satu intervensi yang diberikan pada ibu preeklampsia yang mengalami kecemasan yaitu terapi rendam kaki air hangat. Penelitian bertujuan untuk menganalisis pengaruh terapi rendam kaki air hangat terhadap kecemasan ibu preeklampsia di wilayah kerja Puskesmas Tempurejo Kabupaten Jember. Penelitian ini menggunakan Quasi eksperimental dengan rancangan penelitian yaitu Pretest-posttest with Control Group. Besar sampel 30 ibu preeklampsia dengan menggunakan purposive sampling. Data diperoleh dengan menggunakan kuesioner kecemasan (nilai validitas 0,93 dan nilai reliabilitas 0,97). Analisa data menggunakan uji wilcoxon. Hasil penelitian menunjukkan bahwa terdapat pengaruh terapi rendam kaki air hangat sebanyak 15 orang responden $(p=0,003)$. Sementara pada kelompok kontrol tidak ada pengaruh ( $\mathrm{p}=0,317)$. Uji mann whitney menunjukkan perbedaan signifikan antara kelompok intervensi setelah diberikan terapi rendam kaki air hangat dan kelompok kontrol $(\mathrm{p}=0,000)$. Terapi rendam kaki air hangat merupakan terapi nonfarmakologi yang mampu merangsang hormon endorphin sehingga tubuh merasakan rileks. Efek relaksasi dengan meningkatkan kenyamanan melalui sensasi pada permukaan kaki dan menurunkan kecemasan. Terapi rendam kaki air hangat ini tepat untuk dilakukan pada ibu hamil yang mengalami kecemasan.
\end{abstract}

Kata kunci : Terapi rendam kaki air hangat, kecemasan, ibu preeklampsia

\begin{abstract}
One of psychological error happened on preeclampsia mothers is anxiety disorder. One of the interventions given to preeclamptic women who suffer anxiety is the treatment of warm water foot soak. The research aim to analyze the effect of warm water foot soak therapy on anxiety of preeclampsia women in Puskesmas Tempurejo, Jember Regency. This research used Quasi experimental with a research design of Pretest-posttest with Control Group. The sample was 30 preeclamptic women and used purposive sampling. Data was obtained using an anxiety questionnaire (validity value 0.93 and reliability value 0.97). Data analysis used Wilcoxon. The results of this research showed that there were 15 effects of warm water foot soak therapy $(p=0,003)$. While in the control group there was no influence ( $p=0.317)$. The mann whitney showed significant differences between the intervention groups after being given warm water foot soak therapy and the control group ( $p=0,000)$. Warm water foot soak therapy is a non-pharmacological therapy that can stimulate the endorphin hormone so that the body feels relaxed. The effect of relaxation by increasing comfort through sensations on foot surface and lower the level of anxiety. This warm water foot soak therapy is applicable for pregnant women who suffer anxiety.
\end{abstract}

Keywords: Warm water foot soak therapy, anxiety, preeclampsia women

Sitasi jurnal :

Mangrasih, Rhozy Sadya et al. 2020.The Effect Of Foot Soak Therapy Using Warm Water Toward Anxiety Level Of Preeclampsia Mothers In Public Health Of Tempurejo Jember Regency. Jurnal Ilmu Keperawatan 8 (1): 60-67. Doi 10.21776/ub.jik.2020.008.01.9 


\section{PENDAHULUAN}

Preeklampsia merupakan penyakit vasopastik dengan melibatkan banyak sistem yang dapat meningkatkan morbiditas dan mortalitas maternal dan perinatal (Bobak dkk., 2005). Ibu hamil dengan preeklampsia memiliki tekanan darah sistolik/ diastolik $\geq 140 / 90 \mathrm{mmHg}$.

Menurut WHO dalam Wahyu dkk (2012) kejadian preeklampsia di seluruh dunia mencapai 0,51\%-38,4\%, negara maju angka kejadian preeklampsia sebesar 5\%-6\% dan negara berkembang sebanyak 1:100 sampai 1:1700. Prevalensi kejadian preeklampsia di Jawa Timur sebanyak 30,90\% atau 165 orang (Dinkes Provinsi Jatim, 2016).

Ibu preekalmpsia dapat mengalami gangguan psikologi salah satunya adalah kecemasan Kecemasan merupakan kekhawatiran yang berlebihan yang berkaitan dengan perasaan tidak pasti dan tidak berdaya (Stuart, 2013). Preeklampsia tidak hanya menyebabkan kecemasan namun juga mengancam kesehatan ibu hamil diseluruh belahan bumi (Handayani, 2015).

Angka kejadian kecemasan di Indonesia pada ibu hamil mencapai 373.000.000 (Hasim, 2018). Berdasarkan penelitian yang dilakukan oleh Rudiyanti dan Raidartiwi (2017), kecemasan pada ibu preeklampsia sebesar $86,7 \%$.

Salah satu upaya terapi nonfarmakologi yang diberikan yaitu terapi rendam kaki air hangat. Terapi rendam kaki air hangat memiliki dampak relaksasi dan menyebabkan seluruh aktifitas konstriksi di dalam tubuh menurun sehingga akan menurunkan kecemasan (Pranata dan Yuwanto, 2014).

Berdasarkan penjelasan diatas peneliti tertarik untuk meneliti bagaimana pengaruh terapi rendam kaki air hangat terhadap tingkat kecemasan ibu preeklampsia di Wilayah Kerja Puskesmas Tempurejo.

\section{METODE}

Desain penelitian ini menggunakan Quasi eksperimental dengan pendekatan pretest-postest with control group. Penelitian ini dilakukan di Wilayah Kerja Puskesmas Tempurejo Kabupaten Jember pada bulan Mei sampai Juni 2019. Populasi dari penelitian ini adalah 38 ibu preeklampsia yang telah memenuhi kriteria dan tersebar di 4 desa. Salah satu kriteria inklusi dari penelitian ini yaitu Ibu hamil yang tinggal di Wilayah Kerja Puskesmas Tempurejo, Ibu hamil yang bersedia menjadi responden, Ibu hamil yang mengalami tekanan darah $\geq 140 / 90 \mathrm{mmHg}$, Ibu hamil yang mengalami kecemasan ringan, sedang, berat.

Tehnik samplingyang digunakan untuk mengambil sampel 30 ibu preeklampsia menggunakan purposive sampling. Penelitian ini melihat perbedaan tingkat kecemasan antara pretest dan posttest pada kelompok intervensi dan kelompok kontrol serta perbedaan tingkat kecemasan antara posttest pengukuran pada kelompok intervensi dan kelompok kontrol.

Uji analisa menggunakan wilcoxon untuk mengetahui perbedaan antara pretest dan posttest pengukuran kecemasan pada kelompok intervensi dan kelompok kontrol, serta Uji mann whitney untuk mengetahui perbedaan hasil pengukuran tingkat kecemasan pada kelompok intervensi dan kelompok kontrol. Penelitian menggunakan kepercayaan 95\% dan derajat simpangan $(a=0,05)$.

\section{HASIL}

\section{Data Karakteristik Responden}

Tabel 1 : Distribusi Responden Berdasarkan Usia pada Ibu Preeklampsia Di Wilayah Kerja Puskesmas Tempurejo Kabupaten Jember, ( $\mathrm{n}=\mathbf{3 0}$ ).

\begin{tabular}{ccccc}
\hline Karakteristik & \multicolumn{2}{c}{ Intervensi } & \multicolumn{2}{c}{ Kontrol } \\
\cline { 2 - 5 } Responden & $\begin{array}{c}\text { Jumlah } \\
\text { (orang) }\end{array}$ & $\begin{array}{c}\text { Presentase } \\
\text { (\%) }\end{array}$ & $\begin{array}{c}\text { Jumlah } \\
\text { (orang) }\end{array}$ & $\begin{array}{c}\text { Presentase } \\
\text { (\%) }\end{array}$ \\
\hline Usia & & & & \\
\hline $20-35$ tahun & 7 & 46,7 & 13 & 86,7 \\
\hline
\end{tabular}

Sumber : data primer, Mei-Juni 2019

Berdasarkan tabel 1 karakteristik responden kelompok intervensi yang paling banyak usia 20 35 tahun sebanyak 7 responden $(46,7 \%)$ dan untuk kelompok kontrol usia 20 - 35 tahun sebanyak 13 responden $(86,7 \%)$. 
Tabel 2 : Distribusi Responden Berdasarkan Pendidikan, Pekerjaan dan Paritas pada Ibu Preeklampsia di Wilayah Kerja Puskesmas Tempurejo Kabupaten Jember, $(n=30)$

\begin{tabular}{|c|c|c|c|c|}
\hline \multirow{2}{*}{$\begin{array}{c}\text { Karakteristik } \\
\text { Responden }\end{array}$} & \multicolumn{2}{|c|}{ Intervensi } & \multicolumn{2}{|c|}{ Kontrol } \\
\hline & $\begin{array}{l}\text { Jumlah } \\
\text { (orang) }\end{array}$ & $\begin{array}{c}\text { Presentase } \\
(\%)\end{array}$ & $\begin{array}{l}\text { Jumlah } \\
\text { (orang) }\end{array}$ & $\begin{array}{c}\text { Presentase } \\
(\%)\end{array}$ \\
\hline \multicolumn{5}{|l|}{ Pendidikan } \\
\hline SD & 6 & 40,0 & 7 & 46,7 \\
\hline SMP & 7 & 46,7 & 6 & 40,0 \\
\hline SMA & 2 & 13,3 & 2 & 13,3 \\
\hline \multicolumn{5}{|l|}{ Pekerjaan } \\
\hline Tidak Bekerja & 14 & 93,3 & 14 & 93,3 \\
\hline Wiraswasta & 1 & 6,7 & 1 & 6,7 \\
\hline \multicolumn{5}{|l|}{ Paritas } \\
\hline Nulipara & 2 & 13,3 & 3 & 20,0 \\
\hline Primipara & 3 & 20,0 & 3 & 20,0 \\
\hline Multipara & 10 & 66,7 & 9 & 60,0 \\
\hline
\end{tabular}

Sumber : data primer, Mei-Juni 2019

Berdasarkan tabel 2 karakteritik responden kelompok intervensi dan kontrol paling banyak yaitu pendidikan SD 6 responden (40,0\%), SMP 7 responden $(46,7 \%)$. Pekerjaan responden paling banyak yaitu tidak bekerja. sebanyak 14 responden (93,3\%). Status paritas paling banyak multipara sebanyak 10 responden (66,7\%) dan 9 responden (60.0\%).

Tabel 3: Hasil Pretest - Posttest Tingkat Kecemasan pada Kelompok Intervensi ( $n=15)$.

\begin{tabular}{lccc}
\hline Kondisi & Jumlah & $\begin{array}{c}\text { Presentase } \\
\text { (\%) }\end{array}$ & $\begin{array}{c}\text { Tingkat } \\
\text { Kecemasan }\end{array}$ \\
\hline Pretest & & & \\
\hline & 5 & 33,3 & Ringan \\
\hline 6 & 40,0 & Sedang \\
\hline Posttest & 4 & 26,7 & Berat \\
\hline & 9 & & Ringan \\
\hline 6 & 60,0 & Sedang \\
\hline
\end{tabular}

Sumber : data primer, Mei-Juni 2019

Berdasarkan tabel 3 menunjukkan bahwa sebelum dilakukan terapi terapi rendam kaki air hangat responden mengalami tingkat kecemasan dengan presentase 33,3\% kecemasan ringan, 40,0\% kecemasan sedang dan 26,7\% kecemasan berat. Kemudian setelah dilakukan terapi rendam kaki air hangat presentase pada level kecemasan ringan yaitu $60,0 \%$ dan untuk level kecemasan sedang presentase $40,0 \%$.

Tabel 4: Hasil Uji Wilcoxon pada Tingkat Kecemasan Berdasarkan pretest - posttest pada Kelompok Intervensi $(n=15)$

\begin{tabular}{cccc} 
Kelompok & $\begin{array}{c}\text { Tingkat } \\
\text { Kecemasan }\end{array}$ & $\mathbf{Z}$ & $\mathbf{p}$ \\
\hline Intervensi & Pretest & $-3,000$ & 0,003 \\
& Posttest & &
\end{tabular}

Sumber : data primer, Mei-Juni 2019

Berdasarkan tabel 4 dapat diketahui bahwa hasil dari uji wilcoxon tingkat kecemasan memiliki nilai $\rho<0.05$ yaitu 0,003 . Hal tersebut menunjukan bahwa adanya perbedaan antara pretest - posttest pada kelompok intervensi terapi rendam kaki air hangat.

Tabel 5: Hasil Pretest - Posttest Tingkat Kecemasan pada Kelompok Kontrol $(n=15)$.

\begin{tabular}{lccc}
\hline Kondisi & Jumlah & $\begin{array}{c}\text { Presentase } \\
(\mathbf{\%})\end{array}$ & $\begin{array}{c}\text { Tingkat } \\
\text { Kecemasan }\end{array}$ \\
\hline Pretest & & & \\
\hline & 4 & 26,7 & Ringan \\
\hline Posttest & 3 & 53,3 & Sedang \\
\hline & 20,0 & Berat \\
\hline 4 & 26,7 & Ringan \\
\hline 9 & 60,0 & Sedang \\
\hline
\end{tabular}

Sumber : data primer, Mei-Juni 2019

Berdasarkan tabel 5.5 menunjukkan bahwa pretest pada kelompok kontrol, responden yang mengalami kecemasan ringan memiliki presentase $26,7 \%$, kecemasan sedang $53,3 \%$ dan kecemasan berat $20,0 \%$. Kemudian posttest pada kelompok kontrol, 
responden yang mengalami kecemasan ringan 26,7\%, kecemasan sedang $60,0 \%$ dan kecemasan berat $13,3 \%$.

Tabel 6: Hasil Uji Wilcoxon pada Tingkat Kecemasan Berdasarkan pretest - posttest pada Kelompok Kontrol ( $n=15)$

\begin{tabular}{llcc}
\hline Kelompok & $\begin{array}{c}\text { Tingkat } \\
\text { Kecemasan }\end{array}$ & $\mathbf{Z}$ & $\boldsymbol{p}$ \\
\hline Kontrol & Pretest & $-1,000$ & 0,317 \\
& Posttest & & \\
\hline
\end{tabular}

Sumber : Data Mei-Juni 2019

Berdasarkan tabel 6 dapat diketahui bahwa hasil dari uji wilcoxon tingkat kecemasan memiliki nilai $\rho>$ 0.05 yaitu 0,317 . Hal tersebut menunjukan bahwa tidak terdapat perbedaan yang signifikan antara pretest - posttest pada kelompok kontrol.

Tabel 7: Pengaruh Tingkat Kecemasan pada Kelompok Intervensi dan Kelompok Kontrol

\begin{tabular}{cccc}
\hline Variabel & Kelompok & $\mathbf{Z}$ & $\boldsymbol{P}$ \\
\hline Difference & Intervensi & & \\
& Kontrol & $-4,871$ & 0,000 \\
& & \\
\hline
\end{tabular}

Sumber : Data Mei-Juni 2019

Berdasarkan tabel 7 dapat diketahui bahwa dari hasil mann whitney pada tingkat kecemasan antara kelompok intervensi dan kelompok kontrol memiliki nilai $\rho<0,05$ yaitu 0,000 . Hal tersebut menunjukkan bahwa terdapat perbedaan yang signifikan pada tingkat kecemasan antara kelompok intervensi dan kelompok kontrol.

\section{PEMBAHASAN}

\section{Data Karakteristik Responden}

Usia

Hasil menunjukkan bahwa karakteristik responden berada pada rentan usia 20 - 35 tahun. Rentan usia produktif bukan merupakan faktor resiko kejadian preeklampsia melainkan menjadi usia terjadinya preeklampsia. Menurut penelitian Asmana dkk., (2016) terdapat 162 responden dengan usia $<20$ tahun dan $>35$ tahun sebanyak 66 responden $(40,74 \%)$ dan usia 20 - 35 tahun sebanyak
96 responden (52,26\%). Hasilnya menyatakan terdapat hubungan yang signifikan antara usia dengan kejadian preeklampsia berat $(\rho=0,014)$. Sejalan dengan penelitian Hidayati dan Kurniawati (2015) mengatakan bahwa preeklampsia terjadi pada usia 20-35 dibandingkan usia $<20$ dan $>35$ tahun.

Usiaberkaitan dengan peningkatan dan penurunan fungsi tubuh yang dapat mempengaruhi status kesehatan. Selain itu, usia berkaitan dengan sistem kekebalan tubuh, fungsi sel, serta berkaitan dengan kemampuan memberikan nutrisi dan oksigenasi dari ibu ke janin (Khuzaiyah dan Wahyuni, 2016). Kejadian preeklampsia terjadi karena adanya komplikasi kehamilan yang ditandai dengan tekanan darah tinggi dan tingginya kadar protein urin. Preeklampsia tidak hanya terjadi pada usia $<20$ tahun dan $>30$ tahun melainkan juga terjadi pada usia produktif.

\section{Pendidikan}

Hasil menunjukkan bahwa sebagian besar responden berpendidikan SD dan SMP. Sejalan dengan penelitian Rozhikan (2007) terdapat 100 responden dengan 65 responden $(65,0 \%)$ SD/SLPT dan 35 responden $(35,0 \%)$ SLTA/PT. Hasil menunjukkan tidak terdapat hubungan yang bermakna antara pendidikan dengan kejadian preeklampsia $\rho=1,000$ $(\rho>0,05)$. Berbeda dengan penelitian Gustri dkk., (2016) terdapat 9 responden $(10,0 \%)$ pendidikan rendah, 73 responden $(85,9 \%)$ pendidikan menengah dan 3 responden (3,5\%) pendidikan tinggi. Hasil menunjukkan tidak terdapat hubungan yang bermakna antara pendidikan dengan kejadian preeklampsia ( $\mathrm{p}>$ 0,05).

Pendidikan adalah suatu kegiatan untuk meningkatkan kepribadian, sehingga proses perubahan perilaku menuju kedewasaan dan kesempurnaan kehidupan manusia (Nursal dkk., 2015). Tingkat pendidikan rendah maupun tingkat pendidikan tinggi tidak beresiko untuk mengalami preeklampsia, karena pendidikan dipengaruhi oleh motivasi dan dukungan dalam mencegah terjadinya preeklampsia (Gustri dkk., 2016). Hal ini dapat diketahui bahwa seseorang yang memiliki berpendidikan rendah dan tinggi memiliki peluang untuk terjadi preeklampsia.

\section{Pekerjaan}

Hasil menunjukkan bahwa sebagian besar responden tidak bekerja atau ibu rumah tangga. 
Menurut penelitian Prasetyo dkk., (2015) terdapat 30 responden dengan 28 responden $(93,3 \%)$ tidak bekerja dan 2 responden $(6,7 \%)$ ibu bekerja. Hasil menyatakan terdapat hubungan signifikan antara pekerjaan dengan kejadia preeklampsia $\rho=0,027 \quad(\rho<0,05)$. Sejalan dengan penelitian Lombo dkk., (2017) menyatakan terdapat 60 responden dimana 35 responden (58,3\%), 11 responden (18,3\%) mahasiswa, 5 responden $(8,4 \%)$ PNS, dan 9 responden (15\%) swasta.

Aktivitas pekerjaan mempengaruhi otot dan peredaran darah, hal tersebut terjadi pada ibu hamil dimana terjadi perubahan peredaran darah seiring bertambahanya usia kehamilan akibat pembesaran uterus. Ibu rumah tangga cenderung lebih beresiko mengalami preeklampsia 2 kali lipat dibanding dengan wanita karir atau ibu yang bekerja (Prasetyo dkk., 2015).

\section{Paritas}

Hasil menunjukkan sebagian besar responden adalah multipara. Sehingga dapat dikatakan bahwa paritas multipara merupakan faktor resiko terjadinya preeklampsia. Sejalan dengan penelitian Rozhikan, (2007) dari 100 responden terdapat 31 responden $(31,0 \%)$ paritas primipara dan 69 responden $(69,0 \%)$ paritas multipara. Hal ini menunjukkan terdapat hubungan yang bermakna antara paritas dengan kejadian preekalmsia $\rho=0,031 \quad(\rho<0,05)$. Namun tidak sejalan dengan penelitian Asmana dkk., (2016) menjelaskan bahwa tidak terdapat hubungan yang bermakna antara paritas dengan kejadian preeklampsia berat $\rho=0,096(\rho>0,05)$.

Paritas primipara merupakan faktor utama terjadinya preeklampsia dibandingkan paritas multipara, dimana pada ibu yang pertama kali hamil sering mengalami stress dalam mengahadapi kehamilan dan persalinan yang menyebabkan peningkatan tekanan darah akibat dari pelepasan corcotropic-releasing hormone oleh hipotalamus yang menyebabkan peningkatan kortisol yang dapat meningkatkan tekanan darah (Prasetyo dkk., 2015). Hal ini terjadi ketidaksempurnaan pembentukan blocking antibodies terhadap antigen plasenta, sehingga timbul respon imun yang tidak menguntungkan.

\section{Tingkat Kecemasan Pretest - Posttest Terapi Rendam Kaki Air Hangat pada Kelompok Intervensi}

Berdasarkan hasil penelitian tabel 3 didapatkan tingkat kecemasan pretest intervensi pada kelompok terapi rendam kaki paling banyak dialami oleh ibu preeklampsia yaitu kecemasan sedang dengan 6 responden (40,0\%) adalah kecemasan ringan 5 responden $(33,3 \%)$ mengalami kecemasan ringan, 6 responden $(40,0 \%)$ kecemasan sedang dan 4 responden $(26,7 \%)$ kecemasan berat. Sedangkan kecemasan posttest pada kelompok terapi rendam kaki air hangat adalah 9 responden $(60,0 \%)$ mengalami kecemasan ringan dan 6 responden $(40,0 \%)$ mengalami kecemasan sedang. Penelitian Rudiyanti dan Raidartiwi (2017) menjelaskan hasil penelitian dari 38 responden ibu hamil preeklampsia dengan 15 responden $(39,5,5 \%)$ mengalami cemas dan 23 responden $(60,5 \%)$ mengalami cemas. Sejalan dengan penelitian Darmasanti dkk (2018) menunjukkan bahwa setelah diberikan 3 kali perlakuan responden mengalami penurunan kecemasan, dimana 18 responden yang mengalami kecemasan ringan menjadi tidak cemas dan 18 responden yang mengalami kecemasan sedang berubah menjadi 12 responden mengalami kecemasan ringan dan 6 responden yang mengalami tidak cemas.

Kecemasan yang timbul selama kehamilan dapat disebabkan karena adanya pikiran - pikiran negatif yang terus berkembang. Sehingga kecemasan semakin meningkat akibat respon yang diterima oleh otak memutuskan fight or flight. Hal tersebut membuat suplai oksigen bagi jaringan tubuh meningkat sehingga terjadi ketidakseimbangan jumlah $0^{2}$ dan $\mathrm{C}^{2}$ didalam otak. Ketidakseimbangan $0^{2}$ dan $\mathrm{CO}^{2}$ menyebabkan tubuh menjadi gemetar, susah bernafas, lemah, gangguan penglihatan, meningkatnya kekuatan otot, pegal pada area leher dan kepala nyeri dada (Videbeck, 2012).

Pada hasil penelitian ini menunjukkan terdapat perubahan yang signifikan terhadap tingkat kecemasan ibu preeklampsia pada pengukuran pretest dan posttest sebelum dan sesudah diberikan terapi rendam kaki air hangat. Empat responden sebelum 
diberikan terapi mengalami kecemasan berat setelah diberikan terapi mengalami kecemasan sedang, lima responden sebelum diberikan terapi mengalami kecemasan sedang setelah diberikan terapi mengalami kecemasan ringan dan enam responden mengalami tingkat kecemasan tetap meskipun nilai tingkat kecemasan mengalami penurunan. Penurunan tingkat kecemasan terjadi karena diberikan terapi rendam kaki air hangat, dimana air hangat dapat merangsang hormon endorphin yang akan menurunkan kekuatan saraf simpatik sehingga terjadi vasodilatasi. Kemudian terjadi pelebaran pada pembuluh darah yang membuat tubuh menjadi rileks sehingga akan terjadi penurunan pada hormon kortisol (Carsita dkk, 2018; Ariba Khaliq, 2014; Guyton 2007 dalam Darmasanti dkk., 2018).

Perbedaan tingkat kecemasan pretest dan posttest pada kelompok intervensi di uji menggunakan Wilcoxon (tabel 4), diketahui hasil uji wilcoxon menunjukkan $\rho$ value $<\alpha$ dimana $\alpha=0,05$ sehingga dari hasil penelitian ini dapat diketahui terdapat pengaruh pada tingkat kecemasan pretest dan posttest pada kelompok intervensi.

\section{Tingkat Kecemasan Pretest-Posttest Terapi Rendam Kaki Air Hangat pada Kelompok Kontrol}

Berdasarkan hasil penelitian tabel 5 menunjukkan kecemasan pretest pada kelompok kontrol adalah 4 responden $(26,7 \%)$ mengalami kecemasan ringan, 8 responden $(53,3 \%)$ mengalami kecemasan sedang dan 3 ( 20,0\%) mengalami kecemasan berat. Sedangkan tingkat kecemasan posttest pada kelompok kontrol adalah 4 responden mengalami tingkat kecemasan ringan, 9 responden $(60,0 \%)$ mengalami kecemasan sedang, dan 2 responden (13,3\%) mengalami kecemasan berat. Kecemasan dapat terjadi berkaitan dengan perasaan yang tidak pasti dan tidak berdaya. Menurut Black \& Andreasen sebagaimana yang dikemukakan oleh Mary C Townsend dalam buku yang berjudul Essentials of Psychiatric Mental Helath Nursing (2014) bahwa kecemasan, ketakutan, ketegangan dari kegelisahan dari antisipasi bahaya, sumber sebagian besar tidak dikenal (Rudiyanti dan Raidartiwi, 2017). Tingkat kecemasan sangat berpengaruh terhadap kesejahteraan ibu hamil maupun janin yang didalam kandungan, karena secara tidak langsung dapat memperberat komplikasi dan meningkatkan AKI dan AKB (Siallagen dan Lestari, 2018).
Pada hasil penelitian menunjukkan tidak terdapat perubahan yang signifikan terhadap kecemasan ibu preeklampsia pada pengukuran pretest dan posstest sebelum dan setelah diberikan terapi rendam kaki air hangat. Empat belas responden pretest-posttest pada kelompok kontrol mengalami kecemasan tetap dan satu responden pretest-posttest mengalami kecemasan berat menjadi tingkat kecemasan sedang. Nilai kecemasan yang tetap pada kelompok kontrol disebabkan karena pada kelompok kontrol tidak mendapatkan stimulus untuk meningkatkan relaksasi agar mencapai kondisi nyaman dan rileks yang baik seperti yang diperlakukan pada kelompok intervensi. Kelompok kontrol tidak mendapatkan terapi rendam kaki air hangat, tetapi diberikan pendidikan kesehatan tentang kecemasan pada ibu hamil.

Pendidikan kesehatan merupakan usaha yang dilakukan guna membantu individu, kelompok atau masyarakat untuk meningkatkan kemampuan dalam mencapai kesehatan yang optimal baik fisik maupun psikologi. Hasil dari pendidikan kesehatan berupa perilaku dalam bentuk pengetahuan dan pemahaman, diikuti kesadaran atau sikap positif yang diterapkan pada tindakan pengendalian kecemasan (Rahmat dan Siswosudarmo, 2014). Pendidikan kesehatan penting dilakukan oleh tenaga kesehatan sebagai upaya mengatasi masalah kesehatan baik pada individu, keluarga, kelompok dan masyarakat. Hal tersebut sesuai dengan salah satu peran perawat sebagai edukator atau pendidik.

Perbedaan tingkat kecemasan pretest dan posttest pada kelompok kontrol di uji menggunakan uji wilcoxon (tabel 6), diketahui hasil uji wilcoxon menunjukkan $\rho$ value $>\alpha$ dimana $\alpha=0,05$ sehingga dari hasil penelitian ini dapat diketahui tidak terdapat perbedaan pada kecemasan pretest dan posttest pada kelompok kontrol.

\section{Perbedaan Tingkat Kecemasan Ibu Hamil Preeklampsia pada Kelompok Terapi Rendam Kaki Air Hangat dan Kelompok kontrol}

Berdasarkan tabel 7 hasil mann whitney yang bertujuan untuk mengetahui perbedaan tingkat kecemasan pada kelompok terapi rendam kaki air hangat serta kontrol, $\rho$ value $=0,000$. Hasil menunjukkan bahwa ada perbedaan yang signifikan pada kecemasan antara kelompok intervensi dan kelompok kontrol. 
Menurut Taghavi dkk., (2015) Terapi rendam kaki air menggunakan air hangat merupakan jenis terapi hydrotherapy dengan cara merendamkan kaki ke dalam wadah pada suhu $37^{\circ} \mathrm{C}-39^{\circ} \mathrm{C}$ untuk melancarakan sirkulasi darah dan memberikan efek relaksasi. Air Hangat dapa menyebabkan pembuluh darah melebar sehingga darah yang membawa oksigen akan cepat mencapai jaringan (Chaitow, 2014 dalam Carsita dkk., 2018).

Menurut Pranata dan Yuwanto (2014) terapi rendam kaki air hangat merupakan terapi non farmakologi yang mampu memberikan efek relaksasi dengan meningkatkan kenayaman melalui sensasi pada permukaan kaki dan mampu menurunkan kecemasan pada kecemasan lansia. Berdasarkan penelitian yang dilakukan oleh Darmasanti dkk., (2018) memberikan terapi rendam kaki menggunakan air hangat dengan durasi 10 - 15 menit selama $3 x$ dalam satu minggu pada tingkat kecemasan pada ibu hamil trimester III Di Puskesmas Pegandon Kendal menunjukkan penurunan terhadap tingkat kecemasan.

Penelitian saat ini memberikan terapi rendam kaki air hangat dengan durasi 15- 20 menit dan dilakukan selama 3x dalam satu minggu. Respon relaksasi yang dirasakan oleh ibu hamil preeklampsia berpengaruh terhadap psikologi. Hal ini didasarkan

\section{DAFTAR PUSTAKA}

Ariba, K. (2014). Let Water Take Away Your Troubles: Try Hydrotherapy For Depression And Anxiety. [Serial Online]. Https://Www.Onlymyhealth. Com/Let-Water-Take-Away-Your-TroublesTry-Hydrotherapy-For-Depression-AndAnxiety-1404992885 [20 April 2019]

Asmana, S. K., Yahredi, dan N. Hilbertina. (2016). Hubungan Usia Dritas Dengan Kejadian Preeklampsia Berat Di Rumah Sakit Achmad Mochtar Bukittinggi Tahun 2012-2013. Jurnal Kesehatan Andalas. 5(3):640-646.

Bakshi, R., A. Mehta, and B. Sharma, R. (2007). Tokophobia: Fear Of Pregnancy And Childbirth. The Internet Journal of Gynecology And Obstetrics. 10(1):1-5.

Bere, P. I. D. ., M. Sinaga, dan H. . Fernandez. (2017). Faktor Risiko Kejadian Pre-Eklamsia Pada Ibu Hamil Di Kabupaten Belu. Media Kesehatan Masyarakat Indonesia. 13(2):176-182. pernyataan Pranata dan Yuwanto, (2014) bahwa efek relaksasi yang dihasilkan dari terapi rendam kaki didapatkan dari efek hangat yang memberikan pengaruh melebarkan pembuluh darah terutama pada tubuh.

Terapi rendam kaki air hangat dapat menstimulasi kelenjar pituitary dalam tubuh untuk merangsang hormon endorphin yang akan menurunkan kekuatan saraf simpatik sehingga terjadi vasodilatasi. Vasodilatasi merupakan pelebaran pembuluh darah yang membuat tubuh merasakan rileks sehingga terjadi penurunan pada hormon kortisol (Carsita dkk, 2018; Ariba Khaliq, 2014; Guyton 2007 dalam Darmasanti dkk., 2018).

\section{KESIMPULAN}

Terapi rendam kaki air hangat mampu menurunkan tingkat kecemasan ibu preeklampsia Terapi rendam kaki air hangat dapat merangsang hormon endhorpin dengan menurunkan hormon kortisol. Efek hangat dari terapi rendam kaki dapat memberikan kenyamanan dan tubuh menjadi rileks. Terapi rendam kaki salah satu upaya nonfarmakologi yang tepat digunakan untuk menurunkan tingkat kecemasan pada ibu hamil.

Bobak, Lowdermilk, dan Jensen. (2005). Buku Ajar Keperawatan Maternitas Edisi 4. Jakarta: EGC.

Carsita, W. N., A. R. Herlangga, dan N. R. Puspitasari. (2018). Pengaruh Terapi Rendam Kaki Air Hangat Ditambah Garam Terhadap Tingkat Stress Pekerja Di PT X. 10(2):19-25.

Darmasanti, P., R. Anggraini, dan Setianingsih. (2018). Pengaruh Rendam Kaki Dengan Air Hangat Terhadap Tingkat Kecemasan Pada Ibu Hamil Trimester III Di Puskesmas Pegandon Kendal. Jurnal Keperawatan Dan Pemikiran Ilmiah. $4(1): 1-10$

Dinkes Provinsi Jatim. (2016). Profil Kesehatan Provinsi Jawa Timur

Gusti, N. dan A. Pramita. (2017). Pengaruh Yoga Antenatal Terhadap Tingkat Kecemasan Pada Ibu Hamil Tw Iii Dalam Menghadapi Proses Persalinan Di Klinik Yayasan Bumi Sehat. Jurnal Kesehatan Terpadu 1(1) : 1-5 Issn : 2549 - 8479. 1(1):1-5. 
Gustri, Y., R. J. Sitorus, dan F. Utama. (2016). Determinan Kejadian Preeklampsia Pada Ibu Hamil Di Rsup Dr. Mohammad Hoesin Palembang .Jurnal Ilmu Kesehatan. 209-217.

Handayani, R. (2015). Faktor-Faktor Yang Berhubungan Dengan Tingkat Kecemasan Menjelang Persalinan Pada Ibu Primigravida Trimester III Di Wilayah Kerja Puskesmas Lubuk Buaya Padang Tahun 2012 Reska Handayani Bahwa Visi Rencana Pembangunan Kesehatan Kehamilan Dan Persalinan Di. 11(1):62-71.

Harnani, Y. dan A. Axmalia. (2017). Terapi Rendam Kaki Menggunakan Air Hangat Efektif Menurunkan Tekanan Darah Pada Lanjut. Jurnal Kesehatan Komunitas. 3(5):129-132.

Hasim, R. P. (2018). Gambaran Kecemasan Ibu Hamil. Universitas Muhammdiyah Surakarta.

Johnson, N. (2016). The Use Of Hydrotherapy In Labor To Promote Physiologic Labor. 28.

K, I. S. dan W. P. (2013). Buku Ajar Keperawatan Maternitas. Nuha Medika.

Mathew, C. S., B. Babu, C. Shaji. et all. (2016). INTERNATIONAL Journal of Pharmaceutical And Chemical Sciences Review Article Hydrotherapy : A Review. 5(4):196-200.

Pranata, A. E. Dan M. A. Yuwanto. 2014. Pengaruh Hidroterapi(Rendam Kaki Air Hangat) Terhadap Penurunan Tingkat Kecemasan Pada Lansia Di
Desa Sumbersari Kecamatan Maesan Kabupaten Bondowoso Tahun 2014. Jurnal Kesehatan Dr Soebandi. 2(2):117-121.

Prasetyo, R., H. Wijayanegara, dan A. B. Yulianti. (2015). Hubungan Antara Karakteristik Ibu Hamil Dengan Kejadian Preeklamsi Di Rsud Al-Ihsan Kabupaten Bandung. Prosiding Penelitian Civitas Akademika Unisba. Gelombang (Pendidikan Dokter, Tahun Akademik 2014-2015):10301033.

Rahmat, I. dan R. Siswosudarmo. (2014). Pengaruh Pendidikan Kesehatan Terhadap Kecemasan Primigravida Dalam Menghadapi Persalinan. 1(3):166-174.

Rozhikan. (2007). Faktor-Faktor Risiko Terjadinya Preeklamsia Berat Di Rumah Sakit Dr. H. Soewondo Kendal. 62(1):27-40.

Rudiyanti, N. dan E. Raidartiwi. (2017). Tingkat Kecemasan Pada Ibu Hamil Dengan Kejadian Pre Eklampsia Di Sebuah Rs Provinsi Lampung. Jurnal Keperawatan. XIII(2):173-179.

Siallagen, D. dan D. Lestari. (2018). Tingkat Kecemasan Menghadapi Persalinan Berdasarkan Status Kesehatan, Graviditas Dan Usia Di Wilayah Kerja Puskesmas Jombang. Jornal of Midwivery. 1 (September):104-110.

Taghavi, S., S. Barband, and A. Khaki. (2015). Effect Of Hydrotherapy On Pain Of Labor Process. 28(1) 